\title{
LABOUR FORCE EXPLOITATION AND UNEQUAL LABOUR EXCHANGE AS THE ROOT CAUSE OF THE EUROZONE'S INEQUALITY
}

Ivan RUBINIĆ

Faculty of Law, Rijeka

Maks TAJNIKAR

Faculty of Economics, Ljubliana

UDK: 330.342 .142 (4-6EU) $330.144(4-6 E U)$

Izvorni znanstveni rad

Primljeno: 25. 4. 2018.

The cornerstone of this research is the development of a model which investigates the origins of economic inequality as a derivative of labour force exploitation. The starting point of this inquiry is the theory of unequal labour exchange. The concept being empirically analysed is that the phenomenon of unequal labour exchange between Eurozone countries, arising from exploitation on a national level, plays a key role in creating inequality. The findings indicate that the differences between the capital-labour force ratio and disequilibrium prices enhanced by various levels of economic efficiencies, explain the differences in exploitation rates and arising cross-country inequality.

Keywords: economic inequality, labour force exploitation, unequal labour exchange

Ivan Rubinić, University of Rijeka, Faculty of Law, Economics Department, Hahlić 6, 51000 Rijeka, Croatia. E-mail: irubinic1@pravri.hr

\section{INTRODUCTION}

A soaring number of scientific inquiries into the domain of inequality come as a consequence of extreme disparity among social classes. Despite the extensive literature, contemporary economists have failed to adequately address the subject from the perspective of the theory founded on inequality. The value 
DRUŠ. ISTRAŽ. ZAGREB GOD. 28 (2019), BR. 2, STR. 207-228

RUBINIĆ, I., TAJNIKAR, M.: LABOUR FORCE... theory, as will be shown, can be used as an impressive explanatory tool regarding inequalities and its usage should be reintroduced. In addition to Piketty (2015, p. 26), such a stance is supported by Desai (1974, p. 55), who concludes: "We need value theory to make sense of why prices and profits are what they are and thereby to understand why capitalist societies are ridden by inequality and class divisions".

This paper investigates the cross-country inequalities, through the construction of a model similar to that of Marx, and influenced by the work of Amin (1974). The empirical part of this study encompasses Eurozone's single/unique market, allowing for the straightforward implementation of a theoretical model.

From the Marxian viewpoint, inequality represents an intrinsic component of capitalistic societies arising from the private property institute. To paraphrase Dragičević (1979, p. 1488), inequality represents the result of disparities in production, where there exists a distinction among those who own the means of production and enjoy the surplus value (capitalists) and those who sell their labour and produce the value for the first group (workers)". Consequently, as argued by Bose (1980, p. 10), inequality emerges and its study must depart from the notion of exploitation.

Inequality is further enhanced when the country is involved in international trade. Accordingly, cross-country inequality is studied as a function of the unequal labour exchange arising from exploitation on a national level. This exchange describes how much of the consumed labour used by a country for the production of commodities is, through trade, recognised within that country. In his review of the unequal exchange theories, Brolin (2007) displays the breakdown of the matter, which can serve as an introduction into the topic that is omitted within this paper. According to Brolin, the theory of unequal exchange can be traced back to Ricardian socialists. Among economists dealing with the topic, Bauer, Grossmann, and Prebisch must be mentioned, in addition to Emmanuel who widely popularised the theory. Emmanuel (1972, p. 265) holds unequal exchange as an elementary transfer mechanism, whereby value is transferred from one group of countries to another, enabling the advanced countries to grow at the expense of the less advanced ones. The importance of unequal exchange in the case of the Eurozone is investigated by Seretis \& Tsaliki (2016, p. 449), who concluded that due to the trade "the weak eurozone countries constantly reimburse for the well-being of the strong ones".

The research is based on a set of so-called conclusions, which allow cross-country inequalities to be taken into consideration, in addition to allowing for the authors' transition 
DRUŠ. ISTRAŽ. ZAGREB GOD. 28 (2019), BR. 2, STR. 207-228

RUBINIĆ, I., TAJNIKAR, M.: LABOUR FORCE... from a theoretical to empirical model. The objective of this research is to test whether the economic reality corresponds to the conclusions and to confirm that unequal labour exchange is the cause of the inequality, determining the perspective, and wellbeing of the country.

This research is divided into seven sections. After the introduction, the authors present the model's theoretical framework within the second and third sections. The fourth section is comprised of the empirical model, which uses a data set and assumptions displayed in the fifth section. Section six presents empirical findings. Section seven concludes.

\section{THE UNDERSTRUCTURE OF THE THEORETICAL MODEL}

The economic model is comprised of two coexisting systems. The first being an intrinsic/invisible value system as the expression of abstract labour, and the second being the extrinsic/visible price system based on commodity fetishism. The authors hold that it is in accordance with Marx that these systems are connected through an underlying physical system ${ }^{1}$ which expresses commodity production. Accordingly, the authors assume

Conclusion 1: Price and value systems can be connected via physical surplus, defined as the difference between the total commodities produced and inputs used.

According to van Schaik (1976, p. 3), physical surplus is an essential part of the physical system of a productive economy (an economy in which production exceeds productive consumption). In such a model, the physical system is expressed as

$$
I x-A x=s
$$

where $I$ is the unit matrix, $x$ is the column vector of production, $A$ is the input (coefficient) matrix, and $\mathrm{s}$ is the column vector of physical surpluses. In line with van Schaik (1976, p. $25)$, equation (1) can be rearranged as

$$
s=(I-A) x
$$

A consists of technological coefficients expressing the economy's cross-sector production relations. $A$ is a nontrivial, nonnegative square matrix whose maximum column sum norm is less than one, ensuring the technique $(A, I)$ to be productive (on the set of production vectors where the physical surplus is well defined). Therefore, the existence of the physical surplus is a consequence of the technique properties used.

Conclusion 2 A physical surplus is considered a bundle of commodities which workers, through production, take from nature.

Consequentially, the efficiency of this process and the size of the bundle are determined by the technique used. 
DRUŠ. ISTRAŽ. ZAGREB GOD. 28 (2019), BR. 2, STR. 207-228

RUBINIĆ, I., TAJNIKAR, M.: LABOUR FORCE...
If a physical surplus is expressed as the quantity of labour consumed through its production, or the value of the commodity within the outcome, the result is new value created (hereafter NV). Furthermore, as argued by Marx (1990, p. 293), the commodity value (row) vector $(w)$ equates to the socially necessary abstract labour embodied in the unit of commodity. Part of that labour consists of consumed inputs $(w A)$, while the other part consists of labour consumed for the production of the physical surplus (Bródy, 1970; Okishio, 1963; Weizsäcker, 1973; Wolfstetter, 1973). Formally,

$$
w=w A+l
$$

Moreover, the scalar product between the consumed labour (row) vector $(l)$ and the column production vector is the total labour consumed (L):

$$
\mathrm{L}=l x
$$

By using equations (4), (2), and (3), ${ }^{2}$ the total labour consumed equals the value of the physical surplus (ws):

$$
\mathrm{L}=w s
$$

Therefore, it holds that the value of the physical surplus is the quantity of labour consumed through the production of the physical surplus, i.e. new value created:

$$
\mathrm{NV}=w s=\mathrm{L}
$$

If the physical surplus is expressed through the prices of commodities of which it consists, then such an outcome is the national income (hereafter, NI):

$$
\mathrm{NI}=p s
$$

where $p$ is the commodities price (row) vector.

The physical surplus vector can, in addition to the physical system, be computed using the price system, where the price value of the physical surplus is a dual of physical surplus (van Schaik, 1976, p. 33), defined as:

$$
v=p(I-A)
$$

where $v$ denotes a row vector of the physical surplus in the price system, defined as the difference between the physical surplus output $(p I)$ and input $(p A)$, both expressed in terms of price. Applying equation (2) to (7) and combining the result with equation (8) yields the second expression of the NI:

$$
\mathrm{NI}=p s=v x
$$

Accordingly, Conclusion $3 \mathrm{NV}$ is defined as the expression of the physical surplus in the amount of labour spent on its production, 
DRUŠ. ISTRAŽ. ZAGREB GOD. 28 (2019), BR. 2, STR. 207-228

RUBINIĆ, I., TAJNIKAR, M.: LABOUR FORCE...
From the combination of equations (3), (4), and (8), assuming equivalence between commodity value vector and price vector $(w=p)$, it follows that

$v x=\mathrm{L}$

Consequently,

$\mathrm{NI}=p s=v x=\mathrm{L}=w s=\mathrm{NV}$

In this case, NI is equal to the total quantity of labour consumed, or NV. It must be noted that in reality, the equality between $w$ and $p$ is non-existent because they express distinct categories (labour quantity and monetary magnitudes). However, $w$ and $p$ can be proportionate if the consumed labour is compensated in its entirety by uniform wage rate $\mathrm{w}$, equal to the value of the physical surplus. In that case, the following holds:

$$
v=\mathrm{w} l
$$

Then, the price accounting system follows this equation:

$$
p I=p A+w l
$$

After rearranging, the commodities price vector is obtained as:

$$
p=\mathrm{wl}(I-A)^{-1}
$$

If equations (3) and (14) are combined, it must be the case that:

$$
p=\mathrm{w} w
$$

Equation (15) states that the commodity value vector (w) is proportionate to the price vector, and that the uniform wage rate $(\mathrm{w})$ is the proportionality factor. Acknowledgement of equations (6) and (7) and the uniform wage rate as a proportionality factor, yields equivalence among NI, NV, and the L. ${ }^{3}$

It is imperative to emphasise that the authors did not assume that the sum of the production prices of all commodities is equal to their value, nor that the sum of profits is equal to the sum of surplus values, as was done by numerous researchers (e.g. Borchardt, 1921, p. 36; Desai, 1974; Meek, 1956; Schefold, 2014). The authors base their research on the claim that the physical surplus is reflected in both NV and NI. Accordingly,

Conclusion 4 If the entire physical surplus equates to the total labour invested in production, it must hold that that surplus, even if it is expressed in price terms (NI), is the result of the labour invested in the physical surplus.

If equations (12), (4), and (10) hold, since the wage rate is scalar, it follows that the quantity of the labour used by the 
DRUŠ. ISTRAŽ. ZAGREB GOD. 28 (2019), BR. 2, STR. 207-228

RUBINIĆ, I., TAJNIKAR, M.: LABOUR FORCE... sector is proportionate to the wages received for that labour by the sector. This implies

Conclusion $5 \mathrm{NI}$ of the individual sector is proportionate to the NV of that sector, regarding the quantities of used labour (l) within the sector.

\section{Production Prices, Labour Force Exploitation, and the Competition}

Equation (13) excludes capital and refers to pre-capitalist modes of production. With the industrial revolution and use of machinery, capital emerges and the capitalist's era takes over, altering the fundamental dynamics of production. Since Marx (1991, p. 126) defined capital as the sum of value invested to produce profit, it is straightforward to conclude that the structural revolution comes as the result of economic activity developing into profit driven activity. The production's objective becomes the creation of profits accompanied by the settling of the workers' wages. With that in mind, henceforth, the focus is placed on the distribution of the produced physical surplus between wages and profits (on the distribution of rewards among respective production factors).

The price of the labour force is established on the market under the interaction of supply and demand (Marx, 1947, p. 24). In accordance with Marxian theory, homogenous, competitive, and mobile labour leads to the formation of a unique price of the labour force.

Conclusion 6 In the long-run equilibrium, the labour force must have an equal price in all sectors of the economy.

This price is the theoretical benchmark for labour force mobility and its existence results in the worker's indifference regarding the placement of their labour.

Additionally, profit driven capitalists are moving capital to sectors with high returns. When capital, which is also considered homogenous, competitive, and mobile, reallocates, the increased supply within the high profit rate sectors lowers the profit, while the simultaneous decrease in supply increases profit rates in sectors that were "abandoned". Consequently,

Conclusion 7 The profit rates tend to equalise with the uniform, inter-sector, profit rate. ${ }^{4}$

Hence, the long-run equilibrium price must ensure equalised prices of the labour force and average profit rate. The prices of commodities obtained in this way are the prices of production, i.e. the production price is the sum of the cost price and average profit (Marx, 1991, p. 257; Borchardt, 1921, p. 35). In order to express the production price as Marx did, one must commence with the explanation of the total capital and profit rate. Marx (1991, p. 266) considered the labour cost as variable capital, whereas total capital used was regarded as the sum of 
DRUŠ. ISTRAŽ. ZAGREB GOD. 28 (2019), BR. 2, STR. 207-228

RUBINIĆ, I., TAJNIKAR, M.: LABOÚR FORCE... constant and variable capital. He argued that the profit rate is the relationship between surplus value and total capital used (1991, p. 141). Based on this, Okishio (1963, p. 293) expressed production prices as

$$
p=(1+\pi)(p A+\mathrm{w} l)
$$

where $\pi$ is profit rate. Production prices can also be derived from the work of Sraffa (1960). Whereas, the abovementioned relationship is different (Newman, 1962; van Schaik, 1976, p. 40). Formally,

$$
p=(1+\pi) p A+\mathrm{w} l
$$

In this paper, the authors decided to favour the latter approach. If equations (7), (9), and (17) are connected in aggregate terms, the following holds:

$$
\mathrm{NI}=v x=\pi p A x+\mathrm{w} l x=p s
$$

Note that NI is the physical surplus expressed through the prices of commodities. By using equation (18), the division of the physical surplus into profits and wages takes place. The price of the labour force enables workers to obtain part of the physical surplus $\left(w l x=p s_{w}\right){ }_{1}^{5}$ while the rest remains as profit $\left(\pi p A x=p s-p s_{w}\right)$. If the price of labour were high enough that workers could appropriate the entire physical surplus, profits would be non-existent. Accordingly,

Conclusion 8 Total profit within the economy is the price category received as the difference between the total physical surplus and its part appropriated by workers.

If the physical surplus appropriated by the capitalists is compared to the surplus appropriated by the workers (expressed via commodity values), the result is the exploitation rate $(e)$

$$
e=\left(w s-w s_{w}\right) / w s_{w}
$$

As emphasized by Marx (1990, p. 320) and Morishima (1973, p. 46), e shows how much of the labour workers invest for their reproduction in comparison to how much of their labour is appropriated by capitalists. ${ }^{6}$ Therefore, "a positive rate of exploitation is merely a necessary condition for the existence of positive profit" (Okisio, 1963, p. 293).

Comparison of the prices from equations (13) and (17) indicate that the price vectors would be the same if vector $p A$ were structurally equal to vector $l$. This cannot be expected due to the unequal capital-labour force ratios (hereafter $\mathrm{K} / \mathrm{L})^{7}$ between sectors. Therefore,

Conclusion 9 The sector with an above-average K/L appropriates a higher share of total profits when being compared to other sectors and vice versa. This leads to above-average prices in sectors with above-average $\mathrm{K} / \mathrm{L}$, resulting in a higher share of gained physical 
DRUŠ. ISTRAŽ. ZAGREB GOD. 28 (2019), BR. 2, STR. 207-228

RUBINIĆ, I., TAJNIKAR, M.: LABOUR FORCE... surplus within the given sector.

Consequentially, Conclusion 10: The sectors with aboveaverage $\mathrm{K} / \mathrm{L}$ are appropriating a higher share of the NI of the entire economy.

Since the physical surplus spillover within the sectors is a consequence of technology, the asymmetry arising between sectors is not its outcome. It is the result of the formation of uniform profits influenced by production prices of commodities, constituting physical surplus.

Marx considered two types of competition essential for analysing the importance of market disequilibrium. The first type originates as the outcome of the factor mobility between sectors. Under the influence of this type, average profit and average wage rates are being formed. When such rates are implemented in equations (16) and (17), in accordance with conclusions 6 and 7, production prices are formed. Prior to their formation, existing market prices are fluctuating around the level of production prices, resulting in the creation of the aboveaverage/below-average profits, and leading to

Conclusion 11 The existence of a positive deviation between market and production prices, according to Marx (1991, p. 882), begets the monopoly prices.

This happens since above-average prices within certain sectors lead to below-average prices within other sectors, where it must be stated that the presence of the disequilibrium prices does not alter production prices, nor do they alter the physical surplus from equation (7).

The second type is the consequence of inner-sector dynamics. Founded, as argued by Marx (1991, p. 273), on the motivation to reap the extra profit, ${ }^{8}$ this type incentivises the capitalists to apply the profit maximising technique which, given that the wage rate is fixed, results in minimising costs per unit of production. This competition can be presented via theoretical case by using the price system from equation (17), in which firms use two factors: technique $(A, I)$ and consumed labour (l). If, within sector $j$, a single firm implements a more productive technique $\left(A^{\prime}, I^{\prime}\right)$ and labour $\left(l^{\prime}\right)$, the prices for the sector $j$, as well as average profit and wage rates, will still hold from the equation (17). The firm using an innovative technique will be rewarded with extra profit originating from a more productive performance (Abraham-Frois \& Berrebi, 1979). For this firm, the price equation valid for all other firms within sector $j$, will not hold

$$
p_{j}=(1+\pi) \sum_{i} p_{i} a_{i j}+\mathrm{w} l_{j}
$$

where, $p_{i}$ is the row vector of production prices of inputs within sector $j, a_{i j}$ is the technical coefficient expressing cross- 
DRUŠ, ISTRAŽ ZAGREB GOD. 28 (2019), BR. 2, STR. 207-228

RUBINIĆ, I., TAJNIKAR, M.: LABOUR FORCE... -sector production relations within the economy (the element of $A$ ), and $l_{j}$ is the consumed labour (row) vector within sector $j$. In the case of a more productive firm, the following holds:

$$
p_{j}=(1+\pi) \sum_{i} p_{i} a_{i j}^{\prime}+\mathrm{w} l_{j}^{\prime}+\Pi_{e x, j}
$$

where $\Pi_{e x, j}$ is extra profit within sector $j$, and $a_{i j}^{\prime}$ and $l_{j}^{\prime}$ are the technological coefficient and consumed labour (row) vector, respectively, of the more productive firm.

The $\Pi_{e x}$ remains until the dominant technique is implemented within all firms. In such case, the system from equation (17) would experience alteration consisting of implementation of technology $A^{\prime}$ and labour $l_{j}^{\prime}$. Consequently,

Conclusion 12 The second competition type enhances the position of the firm with above-average productivity by adding extra profit, and leading to superior economic performance.

\section{EMPIRICAL MODEL}

Although Marx was limited to inner-country analysis, the authors argue that applying his approach on a cross-country level is reasonable. This is justified since the analysed countries share a common currency and a single market, which should lead to unobstructed factor mobility. In such an example, matrix $A$ indicates (instead of cross-sectorial) cross-country relationships. In accordance with equation (2), the characteristics of the technique used $(A, I)$ determine the relationship between member states' production, whereas row vector $l$ becomes an indicator of the quantity of the labour consumed within an individual state. Arising from conclusions 2 and 4, the aggregate Eurozone's NI is an expression of the labour invested in the production of the physical surplus within the member states. In such a case, equation (7) holds with the notion that the prices within the equation are proportional to the values (equation 15). From conclusion 5, it follows that the NV of an individual state is indirectly part of the Eurozone's NI, proportional to the quantity of labour consumed given that the wage rates, as factors of proportionality, are the same in all countries.

On these foundations, the authors can calculate the NV of the analysed countries as well as compare the results with the real NI. Deviation between countries' NI and NV is the indicator of how much of the labour used by the country was recognised through the prices of commodities that were produced within that specific country. The latter is what the authors define as "Unequal labour exchange type 1".

Given the specific nature of the Eurozone, the following tendencies are expected: formation of equilibrium prices of goods, services, and labour (conclusion 6), as well as formation 
DRUŠ. ISTRAŽ. ZAGREB GOD. 28 (2019), BR. 2, STR. 207-228

RUBINIĆ, I., TAJNIKAR, M.: LABOUR FORCE... of equilibrium profit rates (conclusion 7). Furthermore, it is reasonable to expect convergence between prices and production prices from equations (16) or (17).

Production prices give the equilibrium national income (hereafter $\mathrm{NI}_{\mathrm{pc}}$ ) based on average equilibrium profit rate $\left(\pi_{\mathrm{pc}}\right)$ and uniformed price of the labour force within equilibrium $\left(\mathrm{w}_{\mathrm{pc}}\right)$ (conclusion 3$) . \mathrm{NI}_{\mathrm{pc}}$ is computed as

$$
\mathrm{NI}_{\mathrm{pc}}=\pi_{\mathrm{pc}}{ }^{*} \mathrm{~K}+\mathrm{w}_{\mathrm{pc}}{ }^{*} \mathrm{~L}
$$

where $\mathrm{K}$ denotes capital. If the sector level is replaced with the cross-country level, the country with an above average $\mathrm{K} / \mathrm{L}$ realises, with the production prices on the market, the above proportional fund of average profits when comparing to the countries with smaller K/L (conclusion 9). Since the differences between $\mathrm{NI}_{\mathrm{pc}}$ and the $\mathrm{NV}$ exist due to the various $\mathrm{K} / \mathrm{L}$ among countries, it is only reasonable to compare them (conclusion 10). The presented theory suggests that the countries with a higher $\mathrm{K} / \mathrm{L}$ should realise a higher $\mathrm{NI}_{\mathrm{pc}}$ in relation to the $\mathrm{NV}$ and vice versa.

When countries with distinct $\mathrm{K} / \mathrm{L}$ ratios are involved in trade according to their equilibrium positions, they trade commodities with equal production prices, equal wages, and equal profit per capital used, but with different quantities of consumed labour. This is what the authors define as "Unequal labour exchange type 2", which occurs within the equilibrium and is a consequence of unequal K/L between countries. This source of cross-country inequality occurs even if the exchange is conducted on a fair-trade principle. ${ }^{9}$

Given that trade, in practice, deviates from the equilibri$\mathrm{um} /$ production prices, market disequilibria need to be investigated. Disequilibria appear as the outcome of the existence of monopolies, imperfect competition, and differentiation of commodities. In trade, countries that achieve above-average profits can use the same production techniques, as well as the same quantities of labour as other countries; this constitutes "Unequal labour exchange type 3". Consequentially, these countries receive higher incomes (conclusion 11) and acquire greater wealth by capitalising on their market positions. To discover the impact of disequilibria on (in)equality, a comparison between the actual NI and $\mathrm{NI}_{\mathrm{pc}}$ must be made. It is worthy to note that equation (7) holds true in the cases of both national incomes, and that both cases are expressing an underlying, equivalent physical surplus. NI is retrieved and consists of real (probably disequilibrium) prices, while $\mathrm{NI}_{\mathrm{pc}}$ is calculated using production/equilibrium prices of commodities. Therefore, countries with higher $\mathrm{NI}$ than $\mathrm{NI}_{\mathrm{pc}}$ are taking advantage of the disequilibria, i.e. for equal quantity of labour used, countries with higher NI than $\mathrm{NI}_{\mathrm{pc}}$ realise commodities with above equilibrium prices. 
DRUŠ. ISTRAŽ. ZAGREB GOD. 28 (2019), BR. 2, STR. 207-228

RUBINIĆ, I., TAJNIKAR, M.: LABOUR FORCE...
The difference between NI and $\mathrm{NI}_{\mathrm{pc}}$ can be reflected in higher profits or a higher price of the labour force, which are disequilibria. Who, among the countries, will be the net-winner depends on the matters within the country itself, especially on the development of the national labour force markets (conclusion 8). This can be investigated on a national level by comparing the differences between NI and $\mathrm{NI}_{\mathrm{pc}}$, with differences between actual and equilibrium prices of the labour force and profit rate.

Considering trade, extra profit can be generated within the national economy (conclusion 12). The origin of extra profit lies in the distinct labour force productivity and capital efficiency, in productions that are organised in various competitors' countries. Prices in this trade reflect the average efficiency and productivity and are, with extra profit, rewarding countries with lower (average) production costs. One part of the NI of the cost-superior sectors reaps extra profit which enlarges the NI of the country comprised of advanced sectors. A part of the NI of the cost-inferior sectors is lowered by the amount of the extra profit from superior sectors, which has a negative effect on the NI of countries with less advanced sectors. This generates "Unequal labour exchange type 4". In this case, prices within equation (7) remain on the price levels from equation (17). However, the technical coefficients within matrix $A$ and the row vector $l$ are altered. Within the cost-superior countries, the consumption of the production factors, per unit of $\mathrm{NI}_{\mathrm{pc}}$ are lower when compared to cost-inferior countries.

The impacts of economic efficiency (labour productivity and capital efficiency) can be investigated using various methods. The authors will address this issue by dividing the profit rates and wage rates into two parts, from which one is used as the measure of economic efficiency. The uniform profit rate can be divided between the share of profits (П) within the NI (П/NI) and the relationship between NI and K (Weisskopf, 1979; Moseley, 1988; Duménil \& Lévy, 2002; Wolff, 2003; Caselli \& Feyrer, 2007; Ferreira, 2011; Chou, Izyumov, \& Vahaly, 2016). Using the same logic, the wage rate (W/L) can be divided between the share of wages $(\mathrm{W})$ in NI (W/NI) and the relationship between NI and L. Relations between NI and K and the NI and L are indicators of capital efficiency and labour force productivity. The higher they are, the higher the economy's efficiency is. It's worth noting that, with the purpose of differentiating between extra profits and the effects of market disequilibria, the authors derive extra profits from equilibrium profit and wage rates.

The Eurozone's average efficiency and productivity were calculated and used to obtain efficient profit rate $\left(\pi_{\mathrm{u}}\right)$ and efficient wage rate $\left(w_{u}\right)$. If such profit and wage rates are used 
DRUŠ. ISTRAŽ. ZAGREB GOD. 28 (2019), BR. 2, STR. 207-228

RUBINIĆ, I., TAJNIKAR, M.: LABOUR FORCE... for individual countries, ceteris paribus, the efficient national incomes (hereafter $\mathrm{NI}_{\mathrm{u}}$ ) that individual countries achieve, under the Eurozone's average productivity and efficiency, can be computed. If $\mathrm{NI}_{\mathrm{u}}$ is compared to $\mathrm{NI}_{\mathrm{pc}}$ the information regarding the loss of countries' $\mathrm{NI}_{\mathrm{pc}}$ due to below-average productivity and efficiency, is received. i.e., the results show how much of the $\mathrm{NI}_{\mathrm{pc}}$ is gained by the countries with aboveaverage efficiency.

The difference between NI and quantity of used labour $(l x)$ within the country is determined by the distinct levels of organic composition of capital, disequilibrium prices of commodities, as well as economic efficiency. Whether these differences are appropriated by workers or capitalists depends on the existing conditions within an individual country's labour markets. This appropriation can be investigated through the exploitation rate from the equation (19).

Exploitation states that the labour invested by workers for production of the surplus consists of two parts. The first part is needed for labour force reproduction and the second is appropriated by the capitalists. If this is investigated through the aspect of labour, the first part represents the necessary labour, while the second part represents the surplus/unpaid labour. This is used to derive the exploitation rate, as did Morishima (1973, pp. 48-49), through the ratio between the unpaid and paid labour:

$$
\mathrm{e}=\frac{\text { Unpaid labour }}{\text { Paid labour }}=\frac{\text { Surplus labour }}{\text { Necessary labour }}=\frac{\mathrm{NV}-\mathrm{W}}{\mathrm{W}}
$$

Given that the total labour invested into production is expressed through a country's NV, and that the paid labour is expressed through non-profit incomes (W), it is straightforward to derive e as the relationship between paid and unpaid labour. It is important to note that the NV of the individual country is proportionate to the labour used in that country, regarding the total labour used in the Eurozone. Both NV and $\mathrm{W}$ are expressed in price terms and their difference represents unpaid labour.

Instead of the real price of the labour force, e can also be computed by using equilibrium prices. Such a category is denoted as $e_{p c}$. Countries where $e_{p c}>$ e will "suffer" from lesser exploitation due to the higher actual price of the labour force, than the price that would be formed in an equilibrium state.

\section{METHODOLOGICAL AND DATA ISSUES}

The empirical analysis covers the Eurozone, excluding Luxembourg. The sample size is determined by the model $^{10}$ and data availability. The authors departed from Sraffa's metaphor of "instantaneous photograph" (see The Sraffa Paper D3/12/13 (1) Sraffa's unpublished notes by Wren Library) or "snapshot", which 
DRUŠ. ISTRAŽ. ZAGREB GOD. 28 (2019), BR. 2, STR. 207-228

RUBINIĆ, I., TAJNIKAR, M.: LABOUR FORCE... depicts the economic system as frozen at one point in time (Arena \& Blankenburg, 2013, p. 8). Hence, the analysis is computed using deflated data from 2004 to 2013, in the form of ten-year annual averages.

The analysis of unequal labour exchange rests on the assumption that inequality is generated in trade within the Eurozone. The same stance is taken by Seretis \& Tsaliki (2016, p. 445). This assumption imposes a constraint since the analysed countries also trade with countries not included in this work. By using World Bank (2017) data, it can be calculated that, on average for Eurozone, intra-group export is $42.61 \%$ of the total export while, intra-group import is $45.18 \%$ of the total import. This limitation does not change the key findings because they are based on the evaluation of the relative position of the country within the group, regarding the unequal labour exchange.

Profit and non-profit (labour) incomes are derived from the United Nations (2016) GDP (Y) calculated as

$$
\mathrm{Y}=\mathrm{W}_{\mathrm{cg}}+\Pi_{\mathrm{cg}}+\mathrm{VA}_{\mathrm{ue}}+\mathrm{T}_{\text {ind }}
$$

where $W_{c g}$ is the remuneration of employees, $\Pi_{c g}$ is the gross surplus of enterprises, $\mathrm{VA}_{\mathrm{ue}}$ is the gross value added of private enterprises (mixed income), and $\mathrm{T}_{\text {ind }}$ are indirect taxes, minus subsidies. In order to differentiate between income types, the profit income is computed as the sum of the incomes earned by enterprises, while the labour income is the residual. $\mathrm{T}_{\text {ind }}$ is considered part of a non-profit income (defined as the labour income). Profit income is computed as

$$
\Pi=\Pi_{\mathrm{cg}}+\mathrm{VA}_{\mathrm{c}}
$$

where $\mathrm{VA}_{\mathrm{c}}$ denotes part of the mixed income earned by enterprises. While the categories of $\Pi_{\mathrm{cg}}$ and $W_{\mathrm{cg}}$ can be con-nected to a particular income source, the question arising is how to determine which part of $\mathrm{VA}_{\mathrm{ue}}$ goes to $\mathrm{VA}_{\mathrm{C}}$ and which part is earned by employees $\left(\mathrm{VA}_{1}\right){ }^{11}$ For this purpose, the authors used Gollin's (2002) approach, which treats mixed incomes as being comprised of the same mix of labour and capital income as the rest of the economy. The advantage of such an approach, besides the creation of country-specific anchors, is that it does not omit the labour income of the self-employed agents. Received values are divided by the total output to receive the specific income shares.

A theoretical category of a country's national income (NI) from equation (7) is taken from the World Bank (2016) and is expressed as GDP in 2011 PPP \$. Derived from the same source is the data on investment expressed in 2011 PPP \$. Conversion to PPP was computed using the World Bank conversion factors and the result was later adjusted by the price index ratio of the investment goods to GDP using the Penn World Tables 9.0. from the University of Groingen (2016). Employment 
DRUŠ. ISTRAŽ. ZAGREB GOD. 28 (2019), BR. 2, STR. 207-228

RUBINIĆ, I., TAJNIKAR, M.: LABOUR FORCE... data is retrieved from EUROSTAT (2016) and consists of information on total employment (20-64). The total amount of labour consumed in each country (L) is treated as homogenous and measured by the number of employed.

Capital variable is estimated, using the perpetual-inventory method based on the annual investment data (Chou, Izyumov, \& Vahaly, 2016; Fraumeni, 1997; Katz \& Herman, 1997), as

$$
\mathrm{K}_{\mathrm{t}}=\mathrm{K}_{0}(1-\delta)^{\mathrm{t}}+\sum_{(\mathrm{n}=0)}^{\mathrm{t}-1)} \mathrm{l}_{\mathrm{t}-\mathrm{n}}(1-\delta)^{\mathrm{n}}
$$

where capital in each year $\left(\mathrm{K}_{\mathrm{t}}\right)$ is a function of the initial capital stock $\left(\mathrm{K}_{0}\right)$, investment $(\mathrm{I})$, and the depreciation rate $(\delta)$. $\mathrm{K}_{0}$ is calculated according to Harberger (1978) using the "stockcapit" command in Stata (Amadou, 2011).

\section{RESULTS AND IMPLICATIONS}

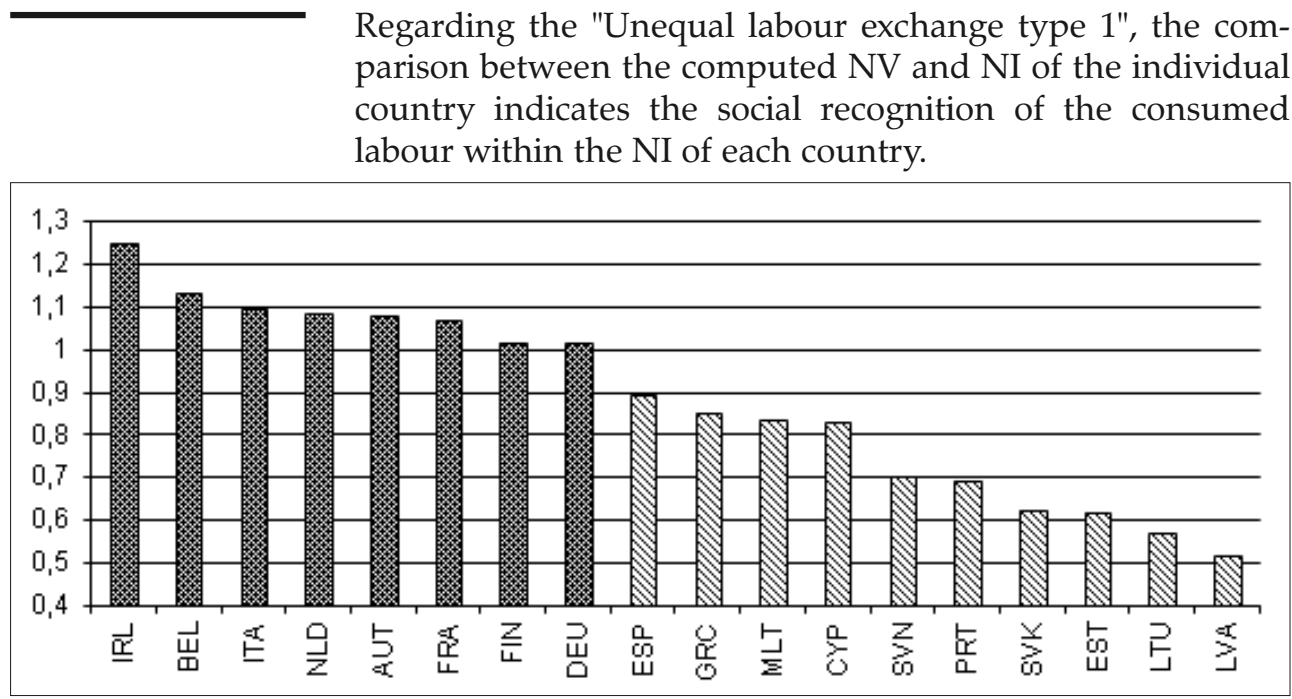

(1) FIGURE 1

The ratio between national income and new value created in the Eurozone (ten-year average for the period 2004-2013)
As depicted, 10 out of 18 countries, ${ }^{12}$ in the form of NI, do not receive the result of labour that was invested in the production of that NI. The worst outcome is obtained in Latvia $(51 \%)$ and the best in Ireland $(125 \%)$. There are, in any given moment, approximately 6.4 million employees from the countries that do not receive recognition of total labour invested in their NI, working for countries that receive more of the recognised labour in their NI than they consumed in the production of surplus. During the reference period, approximately 577 billion 2011 PPP\$ in NI is lost annually by 10 countries in the form of the labour invested and not recognised in the NI.

In accordance with the "Unequal labour exchange type 2", the countries with higher $\mathrm{K} / \mathrm{L}$ should realise a higher $\mathrm{N}_{\mathrm{pc}}$ in relation to the NV. 


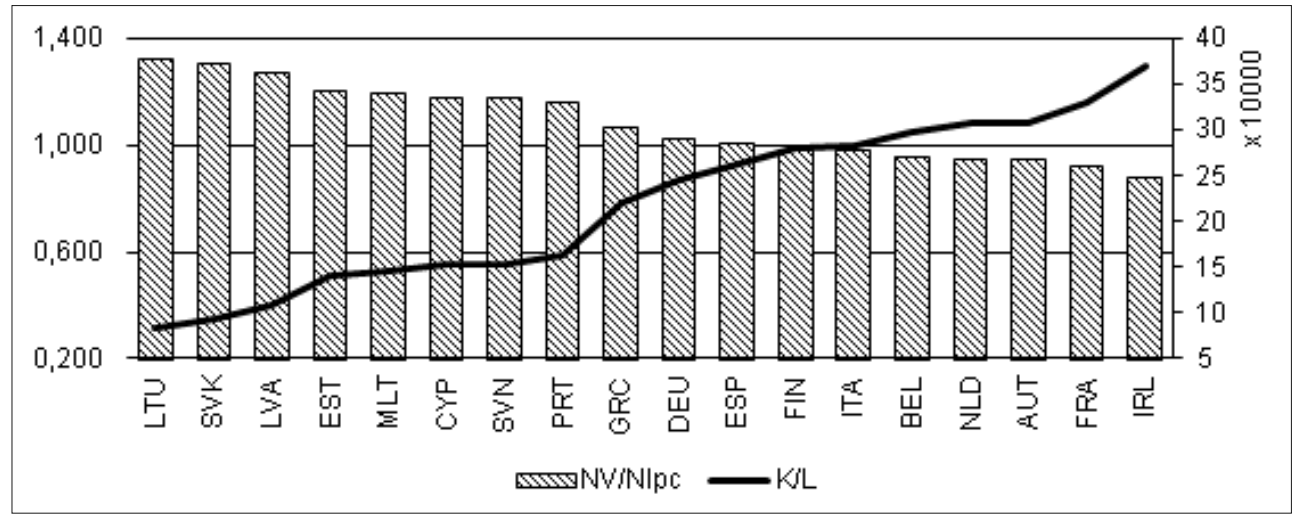

(1) FIGURE 2

The ratio between new value created and equilibrium national income in the Eurozone (ten-year average for the period 2004-2013)

\section{(1) FIGURE 3}

The ratio between actual national income and equilibrium national income in the Eurozone (ten-year average for the period 2004-2013)
$\mathrm{NI}_{\mathrm{pc}}$ is greater than the $\mathrm{NV}$, i.e. the NI which countries would appropriate on the basis of used labour in Ireland, France, Austria, Netherlands, Belgium, Italy, and Finland. These countries also realise an above-average $\mathrm{K} / \mathrm{L}$ (mean is 219,446 ). In Ireland, the highest $\mathrm{K} / \mathrm{L}$ comes along with the biggest difference between the $\mathrm{NI}_{\mathrm{pc}}$ over the NV. The opposite practice occurs in Lithuania. Therefore, even if there is no market disequilibria, the $\mathrm{K} / \mathrm{L}$ in individual countries yields different quantities of labour invested per unit of NI leading to "Unequal labour exchange type 2".

Countries with higher $\mathrm{NI}$ than $\mathrm{NI}_{\mathrm{pc}}$ are taking advantage of the market's disequilibria leading to the creation of the "Unequal labour exchange type 3".

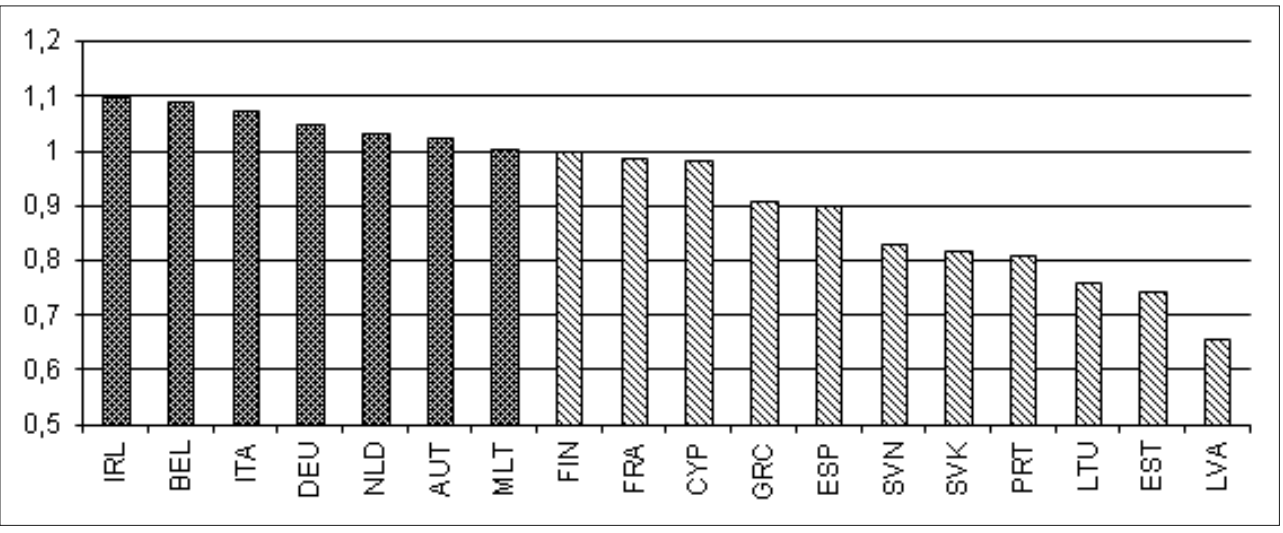

Figure 3 confirms the existence of the "Unequal labour exchange type 3 ". In disequilibrium, the state beneficiaries in higher $\mathrm{NI}$ are Ireland $\left(9.8 \%\right.$ of $\mathrm{NI}_{\mathrm{pc}}$ ), Belgium, Italy, Germany, Netherlands, Austria, and Malta $\left(0.4 \%\right.$ of $\left.\mathrm{NI}_{\mathrm{pc}}\right)$. In contrast, there is Latvia for which the NI is only $65 \%$ of the $\mathrm{NI}_{\mathrm{pc}}$.

Around $36 \%$ of the cumulative NI obtained within the analysed dataset is appropriated by the capital owners, in terms of profit. The remaining consists of the part appropriated by workers and the public sector. Among the countries 
DRUŠ. ISTRAŽ. ZAGREB GOD. 28 (2019), BR. 2, STR. 207-228

RUBINIĆ, I., TAJNIKAR, M.: LABOU UR FORCE...

(1) FIGURE 4

The influence of productivity and efficiency on economic performance of the Eurozone (ten-year average for the period 2004-2013) that have higher NI than $\mathrm{NI}_{\mathrm{pc}}$ the Netherlands and Austria are expressing this difference in above-average prices of the labour force, where the average annual price is 57.2742011 PPP \$. Malta expresses this difference in above-average profit rates. Ireland, Italy, Belgium, and Germany express the difference in both an above-average price of the labour force and above-average profit rates. Latvia, Estonia, Lithuania, Slovenia, Portugal, Greece, Slovakia, and Cyprus are losing NI on markets because their NI is smaller than the $\mathrm{NI}_{\mathrm{pc}}$. However, the latter countries have above-average profit rates, meaning that the losses on the market are at the expense of the labour force. Spain has an NI smaller than the $\mathrm{NI}_{\mathrm{pc}}$ expressed in below-average prices of the labour force and below-average profit rates. Finland and France have NI smaller than $\mathrm{NI}_{\mathrm{pc}}$ and express these differences in the below-average profits and an above-average price of labour. A special case is France with an NI below the $\mathrm{NI}_{\mathrm{pc}}$, but with the highest prices of the labour force (115\% of the equilibrium price) and the lowest profit rates.

The ultimate inequality source is the "Unequal labour exchange type 4", which prevails since the more efficient countries use fewer production factors for the production of a unit of $\mathrm{NI}_{\mathrm{pc}}$ than is the case in cost-inferior countries.

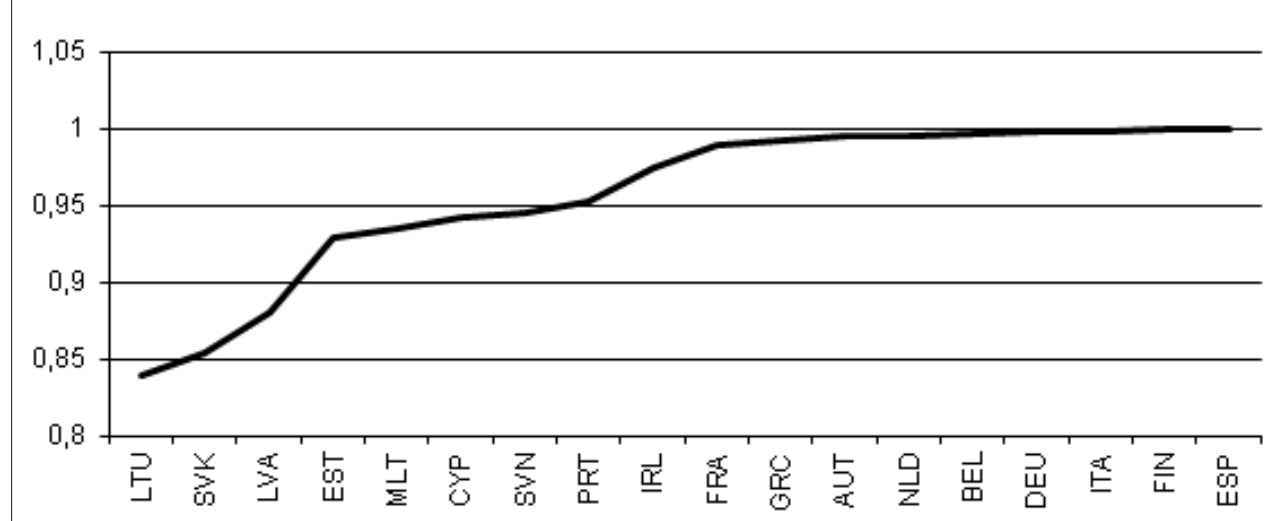

The influence of productivity and efficiency on economic performance was expressed as the ratio between $\mathrm{NI}_{\mathrm{pc}}$ and $\mathrm{NI}_{\mathrm{u}}$. In Lithuania, Slovakia, Latvia, Estonia, Malta, Cyprus, and Slovenia, the $\mathrm{NI}_{\mathrm{pc}}$ is reaching an $84-95 \%$ span of effectiveness $\left(\mathrm{NI}_{\mathrm{u}}\right)$. The characteristic of these countries is that they, in the same order, have a smaller K/L.

Finally, the impact of all the factors affecting the unequal labour exchange is expressed through the distinct national exploitation rates. 


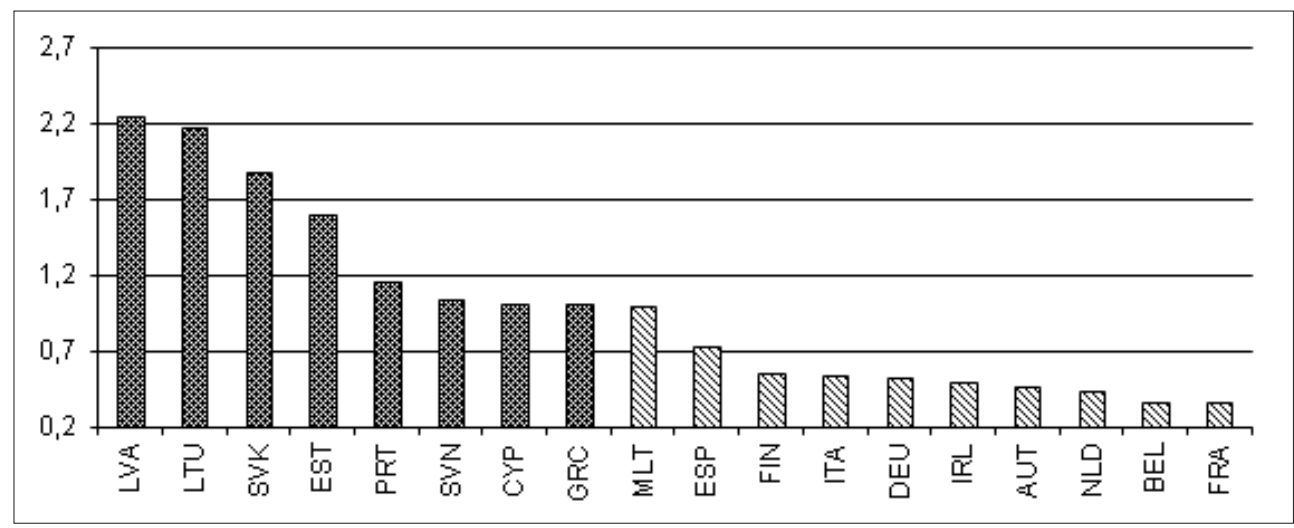

(1) FIGURE 5

The Eurozone exploitation rate (ten-year average for the period 2004-2013)
In France $(e=0.36) 74 \%$ of labour invested in production is used to produce commodities for reproduction of the labour force. On the other hand, in Latvia, workers appropriate only $30 \%$ ( $\mathrm{e}=2.25$ ). The average Eurozone's e is 0.98 meaning that, on average, workers work almost an equal amount of time for themselves as they do for the capitalists.

If the exploitation is computed by using the equilibrium prices, the results indicate that higher exploitation, due to the lower price of the labour force than that in an equilibrium state, is affecting the following countries in descending order: Latvia, Lithuania, Slovakia, Estonia, Portugal, Slovenia, Cyprus, Greece, Malta, and Spain. The rest of the countries are benefiting from this situation.

\section{CONCLUSION}

Under the scope of the paper, the authors investigated the creation of cross-country inequalities within the Eurozone. Based on the results of this research, it can be concluded that unequal labour exchange is an essential concept that generates inequality. The fundamental problem that arises from unequal labour exchange is that with one hour of work, workers realise a different NI within individual countries.

These differences are largely explained by the influence of distinct $\mathrm{K} / \mathrm{L}$ ratios among countries. In cases where one unit of labour is backed by more units of capital, the formation of a uniform profit demands a higher price, which leads to a higher NI per unit of labour force or per unit of labour. The differences in $\mathrm{K} / \mathrm{L}$ ratios are crucial for explaining the differences between GDP per unit of labour force among member states. However, they are not significant in explaining the differences in the prices of the labour force and/or price of capital within the distinct member states.

The influence of the $\mathrm{K} / \mathrm{L}$ is further enhanced by the unequal labour exchange that arises due to market disequilibria 
DRUŠ. ISTRAŽ. ZAGREB GOD. 28 (2019), BR. 2, STR. 207-228

RUBINIĆ, I., TAJNIKAR, M.: LABOUR FORCE... consisting of monopolies, imperfect competition, and differentiation of commodities. Countries that are left in a worse position because of $\mathrm{K} / \mathrm{L}$, in principle, also lose because of market disequilibria (reflected in differences between $\mathrm{NI}$ and $\mathrm{NI}_{\mathrm{pc}}$ ). The deviation among $\mathrm{NI}$ and $\mathrm{NI}_{\mathrm{pc}}$ in certain countries, can explain the level of prices of the labour force. In some countries, the deviation explains both profit rates and the price of the labour force. A unique position goes to France, which has an NI lower than the $\mathrm{NI}_{\mathrm{pc}}$ but, simultaneously, has the highest price of the labour force and the lowest profit rates, when compared to the data set.

In addition, certain countries are losing due to lower labour productivity and capital efficiency. In this case, if a country's economic efficiency were higher, that country would be able to realise higher prices of the labour force and/or higher profit rates.

The combined effects of the unequal labour exchange are manifested within the exploitation rate. Within the Eurozone, there are countries in which workers work more time for the capitalist's profits than for themselves, and countries where the opposite holds.

The results indicate that within the Eurozone, the prices of the labour force are not uniform on a cross-country level. Given that countries share a common currency, theoretical reasoning would argue that labour prices among countries should converge. This does not occur, which indicates underdeveloped labour force mobility. Similar results are received when profit rates are in question. The profit rates among countries are not converging, which means that capital mobility is more of a theoretical construct than an economic reality.

Contemplating on the non-convergence and the cross-country inequalities, one can conclude that the Eurozone countries are far from effective single market integration. Therefore, the existing Eurozone's structure, influenced by the aforementioned economic forces, questions the very values (equality, inclusion, cohesion, and solidarity) upon which it is founded.

Finally, the presented model can serve as a platform for tackling the omitted Eurozone challenges related to, among others, migrations/movers, balance of trade, external debt, etc. Future research should be extended to include the time series analysis, allowing for inquiry into inequality dynamics and serving as the foundation upon which a panel investigation can be performed. The ultimate contribution of which would be the detection of the determinants governing the country's relative position and serving as a basis for the redefinition of the current, sub-optimal, policy decisions. 
${ }^{1}$ This is what Marx (1990, p. 133) refers to as "physical bodies of commodities".

2 Taking into account a strictly positive Leontief-inverse. See van Schaik (1976, p. 29).

${ }^{3}$ This relation is established within equation (11).

${ }^{4}$ This is a sign of a structural matching of supply and demand.

${ }^{5} s_{w}$ is a column vector denoting a part of the physical surplus appropriated by workers.

${ }^{6}$ The capitalist appropriation takes the form of profit once the commodity has been realised on the market.

${ }^{7} \mathrm{~K} / \mathrm{L}$, known in Marxian terminology as the organic composition of capital (1990, p. 762).

${ }^{8}$ The term "extra profit" refers to Marx's "extra-Mehrwert". This term occurs in more than one version, some of which are: surplus profit, super profit, extra profit, and extra surplus-value.

${ }_{9}^{9}$ Emmanuel (1972, p. 163) emphasises that the differentiation of organic composition is inevitable and that it appears even in the model of perfect competition, due to the specific technical features used in production.

${ }^{10}$ The model holds if restrictions on the common currency area and single market are met.

${ }^{11}$ UN-NAS does not differentiate between mixed incomes, according to the source of income.

12 Within all charts, authors used UN (ISO 3166-1 alpha-3) country abbreviations.

Abraham-Frois, A. G., \& Berrebi, E. (1979). Theory of value, prices and accumulation. Cambridge: Cambridge University Press.

Amadou, D. I. (2011). STOCKCAPIT: Stata module to calculate physical capital stock by the Perpetual-Inventory method. Statistical Software Components S457270.

Amin, S. (1974). Accumulation on a world scale. New York: Monthly Review Press.

Arena, R., \& Blankenburg, S. (2013). Sraffa, Keynes, and post-Keynesians: Suggestions for a synthesis in the making. In G. C. Harcourt, \& P. Kriesler (Eds.), The Oxford handbook of post-Keynesian economics, Volume 1 (pp. 62-81). Oxford: Oxford Handbooks Online. https://doi. org/10.1093/oxfordhb/9780195390766.013.0004.

Borchardt, J. (1921). The people's Marx. London: International Bookshop Limited.

Bose, A. (1980). Marx on exploitation and inequality. Delhi: Oxford University Press.

Bródy, A. (1970). Proportions, prices and planning. Budapest: Akadémiai Kiadó. 
DRUŠ. ISTRAŽ. ZAGREB GOD. 28 (2019), BR. 2, STR. 207-228

RUBINIĆ, I., TAJNIKAR, M.: LABOU'UR FORCE...
Brolin, J. (2007). The bias of the world (Doctoral dissertation). Human Ecology Division, Lund University. Available at https://up.lub.lu.se/ search/publication/25251

Caselli, F., \& Feyrer, J. (2007). The marginal product of capital. The Quarterly Journal of Economics, 122(2), 535-568. https://doi.org/10.1162/ qjec.122.2.535

Chou, N. T., Izyumov, A., \& Vahaly, J. (2016). Rates of return on capital across the world: Are they converging? Cambridge Journal of Economics, 40(4), 1149-1166. https://doi.org/10.1093/cje/bev065.

Desai, M. (1974). Marxian economic theory. London: Gray-Mills Publishing. Dragičević, A. (1979). Hrestomatija političke ekonomije (A chrestomathy of the political economy) (vol. 2). Zagreb: Školska knjiga.

Duménil, G., \& Lévy, D. (2002). The field of capital mobility and the gravitation of profit rates (USA 1948-2000). Review of Radical Political Economics, 34(4), 417-436. https://doi.org/10.1016/S0486-6134(02)00177-8

Emmanuel, A. (1972). Unequal exchange: A study of the imperialism of trade. New York: Monthly Review Press.

Eurostat (2016). Total employment 20-64. Available at http://ec.europa.eu Ferreira, A. L. (2011). On the differences between the marginal product of capital across countries. The Manchester School, 79(3), 455-479. https://doi.org/10.1111/j.1467-9957.2009.02163.x.

Fraumeni, B. M. (1997). The measurement of depreciation in the U.S. national income and product accounts. Survey of Current Business, 77, 7-23.

Gollin, D. (2002). Getting income shares right. Journal of Political Economy, 110(2), 458-474. https://doi.org/10.1086/338747.

Harberger, A. (1978). Perspectives on capital and technology in less developed countries. Contemporary economic analysis: papers pres. at the Conference of the Association of University Teachers of Economics, 1, 15-40.

Katz, A., \& Herman, S. (1997). Improved estimates of fixed reproducible tangible wealth, 1929-95. Survey of Current Business, 77, 69-92. Marx, K. (1947). Mezdno delo in kapital (Wage-Labour and Capital). Ljubljana: Cankarjeva založba.

Marx, K. (1990). Capital, Volume 1. London: Penguin.

Marx, K. (1991). Capital, Volume 3. London: Penguin.

Meek, R. L. (1956). Studies in the labour theory of value. London: Monthly Review Press.

Morishima, M. (1973). Marx's economics. Cambridge: Cambridge University Press.

Moseley, F. (1988). The rate of surplus value, the organic composition, and the general rate of profit in the U.S. economy, 1947-67. The American Economic Review, 78(1), 298-303.

Newman, P. (1962). Production of commodities by means of commodities. Swiss Journal of Economics and Statistics, 98(1), 58-75.

Okisio, N. (1963). A mathematical note on Marxian theorems. Weltwirtschaftliches Archiv, 91, 287-298.

Piketty, T. (2015). The economics of inequality. London: Harvard University Press. https://doi.org/10.4159/9780674915565 
DRUŠ. ISTRAŽ. ZAGREB GOD. 28 (2019), BR. 2, STR. 207-228

RUBINIĆ, I., TAJNIKAR, M.: LABOUR FORCE...
Schefold, B. (2014). Profits equal surplus value on average and the significance of this result for the Marxian theory of accumulation. Cambridge Journal of Economics, 40(1), 165-199. https://doi.org/10.1093/ cje/beu077

Seretis, S. A., \& Tsaliki, P. V. (2016). Absolute advantage and international trade: Evidence from four Euro-zone economies. Review of Radical Political Economics, 48(3), 438-451. https://doi.org/10.1177/048661 3415603160

Sraffa, P. (1960). Production of commodities by means of commodities. Cambridge: Cambridge University Press.

United Nations (2016). UN national accounts statistics database. Available at http://unstats.un.org

University of Groingen (2016). Penn world tables 9.0. Available at http://www.ggdc.net/pwt

van Schaik, A. B. T. M. (1976). Reproduction and fixed capital. Tilburg: Tilburg University Press. https://doi.org/10.1007/978-94-011-7970-6

Weisskopf, T. E. (1979). Marxian crisis theory and the rate of profit in the postwar U.S. economy. Cambridge Journal of Economics, 3(4), 341-378. https://doi.org/10.1093/oxfordjournals.cje.a035429

Weizsäcker, C. C. (1973). Modern capital theory and the concept of exploitation. Kyklos, 26(2), 245-281. https://doi.org/10.1111/j.1467-6435. 1973.tb01862.x

Wolff, E. (2003). What's behind the rise in profitability in the US in the 1980s and 1990s? Cambridge Journal of Economics, 27(4), 479-499. https://doi.org/10.1093/cje/27.4.479

Wolfstetter, E. (1973). Surplus labour, synchronised labour costs and Marx's labour theory of value. The Economic Journal, 83(331), 787-809. https://doi.org/10.2307/2230671

World Bank (2016). World development indicators. Available at http:// worldbank.org

World Bank (2017). World integrated trade solutions. Available at http:// wits.worldbank.org

\section{Eksploatacija radne snage i nejednaka razmjena rada kao temeljni uzroci nejednakosti država eurozone}

Ivan RUBINIĆ

Pravni fakultet, Rijeka

Maks TAJNIKAR

Ekonomski fakultet, Ljubliana

Kamen temeljac ovoga rada predstavlja razvoj modela koji istražuje izvore ekonomskih nejednakosti kao derivata iskorištavanja radne snage. Polazište istrage temelii se na teoriji nejednake razmjene rada. Koncept, koji se empirijski analizira koristeći se članicama eurozone, jest taj da je fenomen nejednake razmjene rada između zemalja, kao 
DRUŠ. ISTRAŽ. ZAGREB GOD. 28 (2019), BR. 2, STR. 207-228

RUBINIĆ, I., TAJNIKAR, M.: LABOU'R FORCE... posliedica iskorištavanja na nacionalnoj razini, ključni faktor kreiranja nejednakosti. Rezultati pokazuju da devijacije u omjeru kapital - radna snaga te neuravnotežene cijene povećane raznim razinama ekonomskih učinkovitosti između zemalja objašnjavaju razlike u stopama eksploatacije i nejednakost između zemalia.

Ključne riječi: ekonomska nejednakost, eksploatacija radne snage, nejednaka razmjena rada

\section{(c) (1) (\$)}

Međunarodna licenca / International License:

Imenovanje-Nekomercijalno/ Attribution-NonCommercial 